\title{
CYP2B6 Gene
}

National Cancer Institute

\section{Source}

National Cancer Institute. CYP2B6 Gene. NCI Thesaurus. Code C40049.

This gene is involved in the oxidation of both endogenous substrates and drugs/xenobiotics. 